\title{
Environmental behavior mahasiswa pendidikan akuntansi di kampus konservasi
}

\section{Environmental behavior of accounting education students at the conservation university}

\author{
Ratieh Widhiastutia ${ }^{a}$ Nurdian Susilowati ${ }^{\mathrm{a}}$, Susmy Lianingsih ${ }^{\mathrm{a}}$ \\ ${ }^{a}$ Jurusan Pendidikan Ekonomi, Fakultas Ekonomi, Universitas Negeri Semarang, Gunungpati, Semarang, 50229, Indonesia \\ [+6281326036045]
}

\section{Article Info:}

Received: 11 - 10 - 2019

Accepted: 31 - 05 - 2020

\section{Keywords:}

Environmental behavior; environmental education, conservation

\section{Corresponding Author:} Ratieh Widhiastuti Jurusan Pendidikan Ekonomi, Fakultas Ekonomi, Universitas Negeri Semarang; Tel. +6281326036045

Email:

ratieh.widhiastuti@mail.unnes. ac.id

\begin{abstract}
The purpose of this study was to determine how the conditions of environmental behavior of accounting education students who have finished the Environmental Education Course. The object of the research was the Accounting Education Student of Universitas Negeri Semarang. The research sample was determined using the Slovin formula with 121 students, with random sampling technique. The analysis tool uses descriptive analysis. The results showed that the environmental behavior of students in the category was sufficient, students had high behavior in terms of savings and use of energy sources, the use of environmentally friendly transportation equipment, and the use of goods that cause waste. However, it has weaknesses in behavior in waste management, consumption of environmentally friendly food ingredients is reluctant to be active in environmental organizations and has not been able to utilize social media owned for environmental activities. Suggestions from the results of this study are the need for the practice of prospective creative industry entrepreneurs in learning entrepreneurship courses and optimizing the performance of conservation cadres to increase student awareness of the importance of being involved in environmental organizations.
\end{abstract}

How to cite (CSE Style $8^{\text {th }}$ Edition):

Widhiastuti R, Susilowati N, Lianingsih S. 2020. Environmental behavior mahasiswa pendidikan akuntansi di kampus konservasi. JPSL 10(2): 257-269. http://dx.doi.org/10.29244/jpsl.10.2.257-269.

\section{PENDAHULUAN}

Permasalahan lingkungan menimbulkan ancaman bagi kelestarian lingkungan, diantaranya pemanasan global, polusi udara, kekurangan air, kebisingan lingkungan, dan hilangnya keanekaragaman hayati (Steg dan Vlek, 2009). Selama tahun 2018 kejadian bencana di Indonesia terus mengalami peningkatan. Hampir setiap bulan terdengar berita terjadinya banjir, kebakaran hutan, tanah longsor, gempa, bahkan terjadinya tsunami. Semua bencana alam yang terjadi diakibatkan oleh pemanasan global, menumpuknya sampah anorganik dan pencemaran lingkungan oleh bahan kimia.

Penyebab utama dari segala bencana alam yang terjadi adalah akibat ulah manusia yang tidak bertanggung jawab, dan sikap egoisme yang lebih mementingkan kebutuhan hidup tanpa memedulikan akibat yang akan terjadi kepada lingkungan. Tompodung et al. (2018) menyatakan bahwa timbulnya permasalahan lingkungan tidak terlepas dari adanya peningkatan jumlah populasi manusia di bumi, yang berdampak pada keseimbangan ekosistem dimana tekanan lingkungan hidup menjadi besar akibat ketergantungan hidup manusia pada alam. Berdasarkan laporan Badan Nasional Penanggulangan Bencana (BNPB), selama tahun 2018 telah terjadi 
kejadian bencana sebanyak 2572 kejadian (http://dibi.bnpb.go.id/dibi/). Berdasarkan sebaran kejadian bencana menurut provinsi, jawa tengah merupakan provinsi terbesar yang mengalami kejadian bencana yaitu sebanyak 578 kejadian dalam satu tahun.

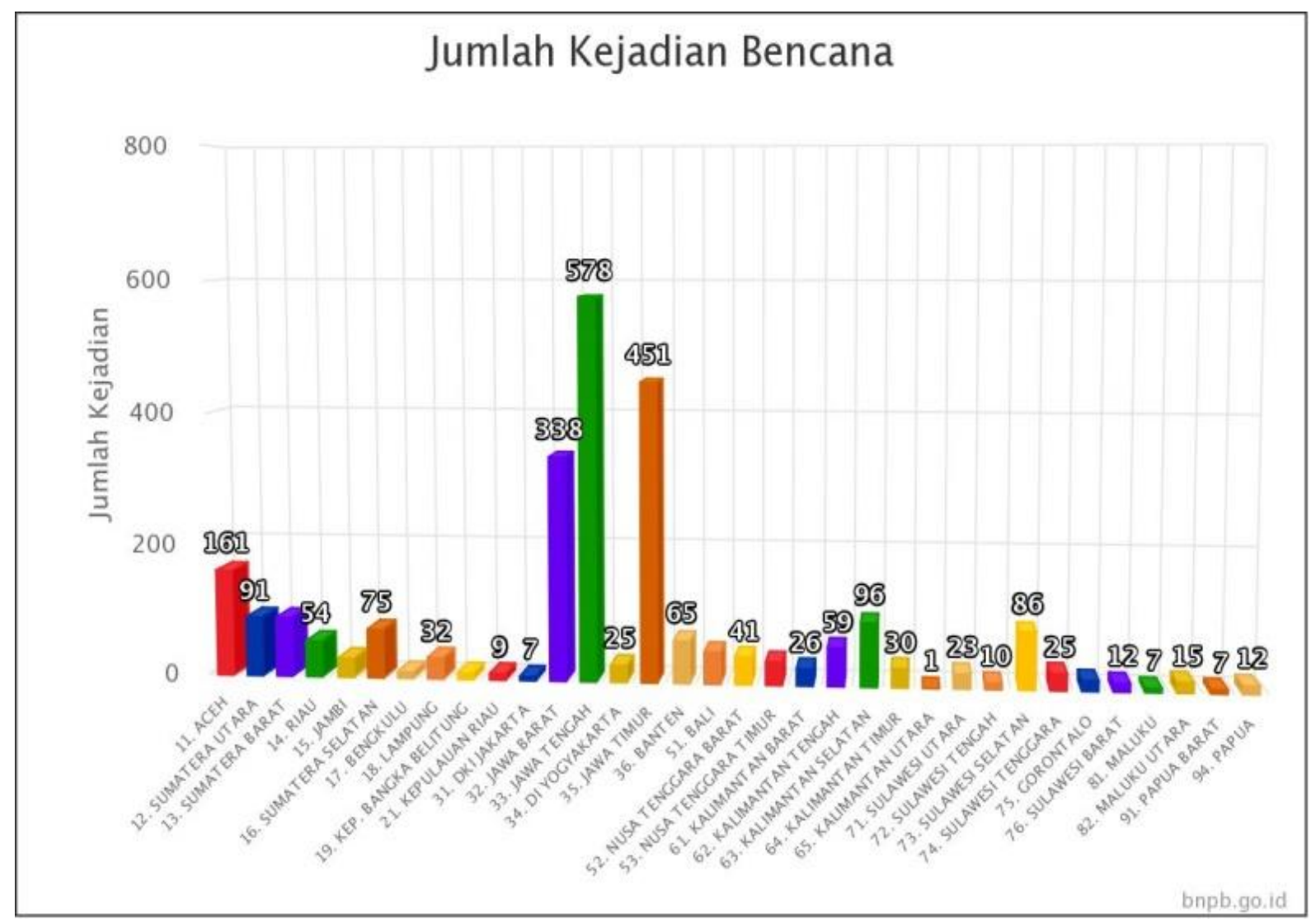

Sumber: Data sekunder BNPB 2018

Gambar 1 Jumlah kejadian bencana di Indonesia tahun 2018

Berdasarkan data pada Gambar 1, apabila tidak dilakukan tindakan-tindakan penanggulangan bencana akan semakin meningkatkan potensi terjadinya bencana yang lebih besar. Universitas Negeri Semarang (UNNES) sebagai salah satu universitas negeri yang ada di Jawa Tengah, memiliki tanggung jawab yang besar untuk dapat menciptakan generasi penerus bangsa yang memiliki perilaku ramah terhadap lingkungan. Menurut Fu et al. (2018) universitas adalah domain sosial yang paling memungkinkan untuk menerapkan kebijakan karena universitas adalah pihak yang menciptakan dan membentuk para pemimpin masa depan, pembuat keputusan, intelektual di bidang sosial, politik, ekonomi, dan akademisi. Telah banyak universitas yang telah menyusun inisiatif kebijakan untuk mengetahui pengaruh perguruan tinggi terhadap lingkungan (Lukman et al., 2013). Rodríguez-Barreiro et al. (2013) menyatakan bahwa telah banyak penelitian yang dilakukan tentang persepsi peserta didik tentang inisiatif lingkungan, seperti kurikulum tentang pendidikan lingkungan, dan kegiatan ekstrakurikuler. Pentingnya memahami sikap dan perilaku siswa terhadap lingkungan dan menemukan cara yang efektif untuk mempengaruhi perilaku tersebut melalui dunia pendidikan, merupakan suatu hal yang tidak dapat diperdebatkan lagi (Zsóka et al., 2013).

Eilam dan Trop (2012) menyatakan bahwa perilaku ramah lingkungan sebagai segala bentuk respons aktif terhadap permasalahan lingkungan, yang diyakini pro-lingkungan oleh orang-orang yang melakukan respon, untuk membentuk perilaku lingkungan diperlukan environmental attitude sebagai prasyaratnya. Perilaku ramah lingkungan sering dikenal dengan istilah environmental behavior, pro-environmental behavior, ecological behavior. Kollmus dan Agyeman (2002) menyatakan bahwa perilaku ramah lingkungan adalah 
tindakan sadar yang dilakukan oleh seseorang dengan maksud untuk meminimalkan dampak negatif dari aktivitas manusia terhadap lingkungan atau untuk memperbaiki lingkungan baik secara langsung maupun tidak langsung. Bechtel dan Churchman (2002) mendefinisikan perilaku ramah lingkungan sebagai perilaku yang memberikan perhatian khusus terhadap lingkungan dalam kehidupan sehari-hari. Perilaku ini bisa berulangulang atau sesekali menyangkut pemeliharaan sumber daya alam maupun lingkungan sekitar, seperti pemeliharaan sumber daya yang spesifik (air, udara, tanah), pengurangan konsumsi sumber energi (listrik, minyak, gas), mendaur ulang (mendaur ulang kertas, plastik, dan lain-lain) serta memelihara kehidupan (tanaman dan hewan).

Norm-Activation Theory merupakan toeri yang dikembangkan oleh Schwartz (2012) untuk menjelaskan perilaku pro-sosial. Menurut teori ini setiap orang memiliki kewajiban moral yang berbeda-beda. Seseorang akan melakukan suatu perilaku sesuai dengan kewajiban moral yang dimiliki. Tindakan pro-lingkungan terjadi karena respon normal personal (personal norm) yang dibentuk oleh kesadaran akan konsekuen dari tindakannya (awareness consequences) dan tanggung jawab seseorang terhadap akibat dari tindakannya tersebut (responsibility belief). Norma personal dikarakteristikkan sebagai aturan yang mengendalikan atau mengontrol perilaku individu, sehingga menimbulkan perasaan untuk melakukan kewajiban untuk bertindak dalam situasi tertentu (Schultz et al., 2005).

Peran norma personal dalam teori ini digunakan untuk menjelaskan sikap terhadap lingkungan. CorralVerdugo dan Frías-Armenta (2006) menemukan keyakinan bahwa norma personal mengenai pemeliharaan air secara langsung mempengaruhi perilaku pro-lingkungan. Nordlund dan Garvill (2003) menghasilkan penelitian bahwa norma personal secara langsung mempengaruhi perilaku pro-lingkungan dan menjadi perantara dampak nilai terhadap perilaku. Awareness of concequences didefinisikan sebagai kesadaran seseorang ketika tidak melakukan tindakan pro-sosial tertentu akan mendatangkan dampak negatif bagi orang lain atau hal lain yang berkaitan. Sedangkan responsibility belief diartikan sebagai perasaan tanggung jawab atas konsekuensi negatif jika tidak bertindak pro-sosial. Teori ini diterapkan secara luas di domain perilaku ramah lingkungan karena kebanyakan orang berperilaku ramah lingkungan didasarkan pada perasaan altruistiknya seperti daur ulang, penerimaan kebijakan energi, dan perilaku ramah lingkungan lainnya secara umum.

Mahasiswa sebagai kaum intelektual yang pada akhirnya menjadi generasi penerus bangsa harus memiliki perilaku yang ramah lingkungan. Menurut Jurdi-Hage et al. (2019); Lin dan Shi (2014); Vicente-Molina et al. (2013), mahasiswa yang sedang menempuh pendidikan di universitas sekarang ini akan mengarahkan hidup manusia secara umum di masa depan, dan calon pemimpin masa depan, dengan demikian mahasiswa harus memberikan solusi dan mengambil tindakan untuk pengembangan lingkungan yang berkelanjutan. UNNES mendedikasikan diri sebagai kampus konservasi, dengan tujuan sebagai salah satu wujud nyata bahwa UNNES sangat mendukung perlunya pelestarian alam lingkungan. Salah satu bentuk komitmen UNNES sebagai kampus konservasi adalah dengan mengintegrasikan mata kuliah Pendidikan Lingkungan Hidup (PLH) dalam kurikulum semua program studi di UNNES tidak terkecuali kurikulum di Jurusan Pendidikan Ekonomi (Akuntansi). Mata kuliah PLH dimaksudkan untuk membekali mahasiswa akan arti pentingnya lingkungan dalam kehidupan, isu-isu lingkungan yang terjadi, dan bagaimana langkah-langkah nyata untuk menjaga kelestarian lingkungan.

Integrasi mata kuliah PLH dalam kurikulum diprediksi mampu meningkatkan kualitas sikap terhadap lingkungan. Seperti yang dinyatakan oleh Mcfarlane dan Boxall (2003) bahwa meskipun pengaruh pengetahuan belum diketahui secara ilmiah, ada beberapa penelitian yang menunjukkan bahwa pengetahuan memainkan peran penting dalam meningkatkan kualitas sikap terhadap lingkungan dan hubungannya terhadap perilaku dengan memberikan individu kemampuan untuk dapat lebih merumuskan pandangan alternatif dan menghadirkan argumen untuk mendukung keyakinan dan perilaku mereka. Jurdi-Hage et al. (2019) menemukan bahwa kesadaran dan pemahaman yang meningkat tentang perubahan isu lingkungan, dan peningkatan keterampilan tindakan bertanggung jawab terhadap lingkungan dapat dikembangkan melalui pendidikan lingkungan. Hal tersebut sesuai dengan peranan universitas sebagai agen perubahan yang efektif. 
Selaras dengan hasil penelitian Meyer (2016) yang menyatakan bahwa kebijakan, program akademik, dan mata kuliah khusus tentang lingkungan dapat mempengaruhi konstruksi preferensi lingkungan mahasiswa karena dapat menambah pengetahuan, keterampilan mahasiswa dalam hal pengembangan nilai dan kepedulian terhadap lingkungan.

Tujuan penelitian ini adalah untuk mengetahui bagaimana kondisi perilaku ramah lingkungan yang dalam penelitian ini akan menggunakan istilah environmental behavior mahasiswa Jurusan Pendidikan Akuntansi semester lima yang telah selesai menempuh mata kuliah PLH. Mahasiswa Pendidikan Akuntansi semester lima adalah termasuk generasi $\mathrm{Z}$ yang memiliki kecenderungan untuk bersikap semaunya sendiri, bebas, dan ekspresif, sehingga perlu diketahui sejak awal bagaiman kecenderungan mahasiswa pendidikan akuntansi dalam menyikapi lingkungan. Berdasarkan hasil pengamatan masih sering ditemui mahasiswa yang membuang sampah sembarangan meskipun sudah disediakan tempat sampah sesuai dengan sifat sampah organik dan an-organik, kurang peka terhadap lingkungan, masih membeli makanan dan minuman yang menggunakan kemasan plastik yang tidak dapat didaur ulang.

Ketertarikan untuk melihat bagaimana perilaku mahasiswa pendidikan akuntansi dalam memperlakukan lingkungan dilatarbelakangi karena keunikan dari objek penelitian. Lulusan pendidikan akuntansi merupakan calon tenaga pendidik yang muaranya bisa menjadi guru maupun dosen. Seorang tenaga pendidik harus memiliki kepribadian yang baik termasuk bagaimana perilaku bersosialisasi dengan lingkungan sekitar. Tindak tanduk seorang tenaga pendidik akan dicontoh oleh peserta didik, sehingga sudah sewajarnya mahasiswa pendidikan akuntansi UNNES harus sudah terbiasa untuk berperilaku ramah terhadap lingkungan. Di sisi lain, mahasiswa pendidikan akuntansi telah mendapatkan kompetensi dalam mata kuliah keekonomian dan keuangan yang di dalamnya mengajarkan mahasiswa untuk memiliki kemampuan dalam mengatur keuangan (financial literacy) yang cerdas sesuai dengan urutan terpenting termasuk membelanjakan uang untuk membeli barang-barang yang ramah lingkungan.

\section{METODE}

\section{Metode Pengumpulan Data}

Penelitian ini merupakan penelitian survei sederhana dengan menggunakan kuesioner yang ditujukan untuk mengukur kondisi perilaku ramah lingkungan mahasiswa. Objek penelitian adalah mahasiswa Pendidikan Akuntansi angkatan 2016 yang telah menempuh mata kuliah PLH. Sampel penelitian ditetapkan menggunakan Rumus Slovin dengan teknik pengambilan sampel random sampling dan diperoleh sampel sebanyak 121 mahasiswa. Alat analisis menggunakan analisis deksriptif. Pengukuran environmental behavior yang digunakan dalam penelitian ini diukur menggunakan General Ecological Behavior Scale (GEBS) yang dikembangkan oleh Kaiser et al. (1999) yang telah direvisi pada tahun 2004.

\section{Metode Analisis Data}

Kuesioner menggunakan skala likert lima tingkat untuk mengetahui sejauh mana perilaku mahasiswa dalam menjaga kelestarian lingkungan. Perilaku manusia terhadap lingkungan yang diukur dari enam dimensi: (1) energy conservation, perilaku-perilaku yang menunjukkan penghematan dan efisiensi pemakaian energi; (2) mobility and transportation, perilaku-perilaku yang menunjukkan pemakaian moda transport yang ramah lingkungan; (3) waste avoidance, perilaku-perilaku yang menghindari pemakaian yang akan menghasilkan limbah; (4) consumerism, perilaku-perilaku konsumsi yang ramah lingkungan; (5) recycling, perilaku-perilaku daur ulang; dan (6) vilarious, social behaviors toward conservation, perilaku-perilaku sosial yang menggambarkan kepedulian terhadap lingkungan. Setiap dimensi pengukuran perilaku ramah lingkungan terdiri dari lima indikator pertanyaan sehingga total pernyataan untuk mengukur environmental behavioral terdiri dari 30 pernyataan. Dari hasil sebaran jawaban responden selanjutnya dikelompokkan menjadi lima kriteria, yang dikelompokkan berdasarkan Tabel 1. 
Tabel 1 Jenjang kriteria environmental behavior per-dimensi pengukuran

\begin{tabular}{ccc}
\hline No & Rentang & Kriteria \\
\hline 1 & $21-25$ & sangat tinggi \\
2 & $17-20$ & tinggi \\
3 & $13-16$ & sedang \\
4 & $9-12$ & rendah \\
5 & $5-8$ & sangat rendah \\
\hline
\end{tabular}

Sumber: Data primer diolah, 2018

\section{HASIL DAN PEMBAHASAN}

Perilaku ramah lingkungan tidak hanya terbatas pada kebiasaan membuang sampah pada tempatnya, namun lebih luas dan butuh pengorbanan dan pembiasaan dalam melaksanakannya. Perilaku yang menjaga kelestarian lingkungan meliputi kebiasaan menghemat energi, pemakaian alat transportasi yang ramah lingkungan, perilaku konsumsi dan pemakaian bahan-bahan yang berbahaya terhadap lingkungan, sampai dengan perilaku sosial yang menggambarkan sikap ramah terhadap lingkungan. Berdasarkan hasil penelitian atas 6 dimensi pengukuran perilaku mahasiswa terhadap lingkungan secara ringkas dijelaskan pada Tabel 2.

Tabel 2 Hasil environmental behavior dari enam dimensi pengukuran

\begin{tabular}{clccc}
\hline No. & \multicolumn{1}{c}{ Dimensi Pengukuran } & Rata-rata & Persentase (\%) & Kategori \\
\hline 1 & Energy conservation & 19 & 64 & tinggi \\
2 & Mobility and transportation & 17 & 50 & tinggi \\
3 & Waste avoidance & 13 & 47 & cukup \\
4 & Consumerism & 19 & 64 & tinggi \\
5 & Recycling & 15 & 48 & cukup \\
6 & Vilarious, social behaviors toward & 13 & 47 & cukup \\
\hline
\end{tabular}

Sumber: Data primer diolah, 2018

Berdasarkan Tabel 2 diketahui bahwa dalam empat dimensi pengukuran environmental behavior, mahasiswa pendidikan akuntansi dalam kategori tinggi. Mahasiswa Pendidikan Akuntansi telah memiliki perilaku yang menunjukkan penghematan dan efisiensi pemakaian energi dengan sangat baik, selain itu kebijakan UNNES untuk menggunakan sepeda di lingkungan kampus sangat bermanfaat membentuk perilaku mahasiswa terbiasa menggunakan alat transportasi yang ramah lingkungan. UNNES melalui Unit Pelayanan Terpadu (UPT) Pengembang Konservasi melaksanakan misi melalui kegiatan pengabdian kepada masyarakat sebagai upaya pemecahan permasalahan lingkungan pada tingkat lokal dan global. Dalam pelaksanaan kegiatan pengabdian, UPT Pengembang Konservasi mengajak mahasiswa sebagai kader konservasi untuk melaksanakan program. Mahasiswa kader konservasi diajarkan membuat produk-produk inovasi dari sampah daur ulang, yang dapat bermanfaat bagi diri sendiri maupun masyarakat luas.

Perilaku mahasiswa pendidikan akuntansi terkait waste avoidance, recycling dan vilarious, social behaviors toward conservation dalam kategori cukup. Mahasiswa tidak bisa menjauhkan diri dari kebiasaan untuk menggunakan tisu dalam kehidupan sehari-hari, selalu menggunakan kantong plastik setiap belanja terutama saat membeli makanan. Mahasiswa pendidikan akuntansi belum aktif untuk mengikuti organisasi lingkungan, masih mengikuti kegiatan lingkungan karena faktor tuntutan berupa kegiatan yang diwajibkan oleh Universitas untuk diikuti mahasiswa. Mahasiswa belum memiliki tanggung jawab personal untuk senantiasa menjaga lingkungan, sehingga mahasiswa belum memiliki kepedulian untuk terlibat dalam berbagai kegiatan dan organisasi lingkungan. Harland et al. (2007) melakukan penelitian di Belanda dan menemukan bahwa individu yang merasa memiliki kewajiban personal untuk menjadi relawan akan memiliki keinginan 
lebih kuat untuk menjadi sukarelawan di organisasi lingkungan. Hasil penelitian atas perilaku environmental behavior mahasiswa pendidikan akuntansi dilihat dari enam dimensi lebih rinci dijelaskan sebagai berikut.

\section{Aktivitas Penghematan dan Efisiensi Penggunaan Sumber Energi (Energy Conservation)}

Pengukuran kebiasaan penggunaan dan efisiensi penggunaan sumber energi diukur dengan lima pernyataan, yaitu kepemilikan peralatan elektronik hemat energi, pemanfaatan sirkulasi udara yang baik di ruangan, pembatasan pemakaian listrik, penggunaan lampu tidur pada malam hari, dan mematikan peralatan listrik saat tidak digunakan. Berdasarkan hasil penelitian diketahui bahwa rata-rata mahasiswa pendidikan akuntansi telah melakukan penghematan listrik dalam kehidupan sehari-hari. Meskipun kondisi cuaca pada saat pengambilan data penelitian ini dilakukan menunjukkan cuaca terpanas sepanjang tahun 2018, namun mahasiswa Pendidikan Akuntansi memiliki kebiasaan untuk mencari udara melalui jendela atau pintu pada siang hari sebagai media pertukaran udara, daripada menggunakan kipas angin atau air conditioner (AC). Kepala Seksi Data dan Informasi BMKG Stasiun Klimatologi Kota Semarang melaporkan bahwa Bulan Oktober merupakan bulan terpanas di Kota Semarang sepanjang tahun 2018. Suhu udara tertinggi pada bulan Oktober rata-rata mencapai $35.9^{\circ} \mathrm{C}$, posisi matahari berada di selatan equator sehingga suhu udara menjadi panas. Hal ini menunjukkan bahwa mahasiswa pendidikan akuntansi lebih menikmati udara alami daripada menggunakan sumber energi pengganti.

Mahasiswa pendidikan akuntansi UNNES mayoritas berasal dari keluarga yang memiliki kondisi sosial ekonomi menengah ke bawah, sehingga tidak memiliki kemampuan lebih untuk membeli peralatan elektronik yang hemat energi. Ritter et al. (2015) menyatakan bahwa budaya dan status sosial-ekonomi memainkan peran penting terhadap dampak lingkungan dan mempengaruhi konsumsi green products. Mahasiswa memiliki kecenderungan untuk membeli peralatan elektronik yang murah terjangkau dengan daya beli meskipun lebih tinggi daya pemakaian listrik.

Tabel 3 Hasil perilaku mahasiswa dalam penghematan dan efisiensi pemakaian energi (energy conservation)

\begin{tabular}{clcc}
\hline No. & \multicolumn{1}{c}{ Perilaku } & Rata-rata & Kategori \\
\hline 1 & Kepemilikan peralatan elektronik yang hemat energi & 3 & cukup \\
2 & $\begin{array}{l}\text { Penggunaan jendela atau ventilasi udara untuk sirkulasi } \\
\text { udara }\end{array}$ & 4 & tinggi \\
3 & Mematikan listrik saat tidak digunakan & 4 & tinggi \\
4 & Pembatasan listrik di kos untuk menjaga kelestarian & 4 & tinggi \\
5 & lingkungan & 3 & cukup \\
\hline
\end{tabular}

Sumber: Data primer diolah, 2018

\section{Perilaku yang Menunjukkan Pemakaian Transportasi Ramah Lingkungan (Mobility and}

\section{Transportation)}

Transportasi merupakan salah satu sumber penyebab munculnya permasalahan lingkungan terutama dalam hal penyediaan bahan bakar dan pencemaran dari polusi yang ditimbulkan (Hidup, 2009). Bagaimana cara pemilihan alat trasportasi akan sangat mempengaruhi lingkungan, semakin sedikit mahasiswa yang menggunakan kendaraan pribadi akan semakin mengurangi terjadinya polusi. Jumlah kawasan hijau yang terdapat di sekitaran kampus UNNES sudah mulai berkurang seiring dengan bertambahnya jumlah perumahan penduduk. Hal ini berarti jumlah pohon yang digunakan untuk menyaring karbon dioksida semakin berkurang, sehingga apabila mahasiswa semakin banyak yang lebih memilih kendaraan pribadi akan sangat memperburuk kondisi lingkungan khususnya udara sekitar. 
Berdasarkan hasil penelitian menunjukkan bahwa jumlah mahasiswa yang menggunakan kendaraan pribadi baik sepeda motor maupun mobil, jumlahnya sama banyak dengan mahasiswa yang lebih memilih untuk menggunakan alat transportasi umum. Namun demikian, mahasiswa pendidikan akuntansi lebih memilih untuk menggunakan transportasi umum untuk menuju lokasi yang jaraknya dekat. Hal ini didukung oleh kemajuan transportasi online yang mudah untuk dijangkau di daerah kampus. Arif et al. (2009) menyatakan bahwa penggunaan kendaraan umum seperti bus dapat menghemat $10 \%$ bahan bakar yang digunakan kendaraan pribadi. Sementara emisi karbon yang ditimbulkan bus per-orang per-kilometer perjalanan hanya $13 \%$ dari emisi sepeda motor dan $6 \%$ dari mobil pribadi.

Perilaku peduli lingkungan dalam penggunaan transportasi, tidak hanya diukur dalam penggunaan alat transportasi, namun juga dilihat dari sisi perawatan kendaraan. Hidup (2009) menyatakan bahwa perawatan kendaraan secar rutin selain bermanfaat untuk mencegah rusaknya mesin juga berhubungan dengan penghematan bahan bakar dan mengurangi polusi yang ditimbulkan. Berdasarkan hasil penelitian, diketahui bahwa mahasiswa pendidikan akuntansi telah melakukan perawatan kendaraan pribadi secara teratur, namun hanya terbatas pada servis rutin bulanan.

Tabel 4 Hasil perilaku mahasiswa dalam pemakaian alat transportasi (mobility and transportation)

\begin{tabular}{|c|c|c|c|}
\hline No. & Perilaku & Rata-rata & Kategori \\
\hline 1 & Mengunakan kendaraan pribadi saat bepergian jauh & 4 & tinggi \\
\hline 2 & $\begin{array}{l}\text { Mengunakan kendaraan pribadi saat menuju tempat yang } \\
\text { dekat }\end{array}$ & 3 & cukup \\
\hline 3 & $\begin{array}{l}\text { Menggunakan transportasi umum, sepeda, atau berjalan } \\
\text { kaki ketika menuju kampus }\end{array}$ & 4 & tinggi \\
\hline 4 & $\begin{array}{l}\text { Pembatasan listrik di kos untuk menjaga kelestarian } \\
\text { lingkungan }\end{array}$ & 3 & cukup \\
\hline 5 & Perawatan kendaraan pribadi secara baik dan teratur & 4 & tinggi \\
\hline
\end{tabular}

Sumber: Data primer diolah, 2018

\section{Perilaku Menghindari Pemakaian Barang yang Menyebabkan Limbah (Consumenarism)}

Berdasarkan data dari Badan Pusat Statistik (BPS) Indonesia tahun 2018, menunjukkan bahwa Negara Indonesia merupakan negara terbesar kedua yang menyumbang sampah plastik di dunia. Hal tersebut disebabkan karena konsumsi masyarakat yang lebih memilih makanan instan yang dikemas dalam kemasan plastik, dan kebiasaan masyarakat untuk menggunakan kantong plastik dalam setiap transaksi belanja. Meskipun pemerintah telah mengeluarkan Peraturan Pemerintah Nomor 81 Tahun 2012 tentang Pengelolaan Sampah Rumah Tangga dan Sampah Sejenis Sampah Rumah Tangga, di mana pemerintah melakukan pelarangan terhadap penyediaan kantong belanja plastik di toko ritel modern tidak mengurangi minat masyarakat untuk tetap menggunakan plastik sebagai tempat penyimpanan belanja. Mahasiswa pendidikan akuntansi UNNES sudah memiliki ketergantungan akan plastik, sebagian besar mahasiswa tidak memasak untuk kegiatan makan setiap harinya. Mahasiswa selalu membeli makanan di warung untuk setiap kegiatan konsumsi, di mana semua makanan akan dibungkus dalam kertas dan dimasukkan ke dalam plastik. Tidak bisa terhindarkan berapa banyak sampah plastik yang dihasilkan mahasiswa setiap harinya.

Mahasiswa pendidikan akuntansi sebagian besar adalah wanita, sehingga penggunaan tisu dalam aktivitas sehari-hari menjadi perlengkapan yang tidak bisa dihindarkan. Untuk membersihkan apapun, mahasiswa pendidikan akuntansi menggunakan tisu, tidak menggunakan lap kain yang bisa digunakan berkali-kali. Namun demikian, karena tingkat daya beli mahasiswa pendidikan akuntansi dalam kategori sedang, maka sampah dari makanan kemasan yang dihasilkan mahasiswa sangat rendah. Mahasiswa lebih memilih masakan segar yang langsung dibeli di warung atau rumah makan terdekat dari tempat kos daripada membeli makanan kalengan atau minuman kemasan. Di aspek lain, berdasarkan hasil pengisian kuesioner diketahui bahwa 
mahasiswa memiliki kecenderungan untuk membakar sampah sebagai cara untuk mengurangi sampah. Hal ini sungguh sangat tidak dianjurkan karena selain akan merusak kesuburan tanah juga akan mengotori udara di sekitar tempat tinggal mahasiswa.

Marliani (2014) menyatakan bahwa apabila sampah plastik dibakar, akan menghasilkan asap beracun yang berbahaya bagi kesehatan yaitu jika proses pembakarannya tidak sempurna maka plastik akan mengurai di udara sebagai dioksin yang dapat memicu penyakit kanker, hepatitis, pembengkakan hati, gangguan sistem saraf dan memicu depresi. Ikhsandri (2014) menyatakan tindakan membakar sampah merupakan salah satu teknik pengolahan sampah, akan tetapi pembakaran sampah dilakukan di lapangan yang jauh dari pemukiman. Pembakaran yang baik yaitu dilakukan dengan incinerator agar tidak menimbulkan gangguan akan tetapi memerlukan biaya yang mahal.

Tabel 5 Hasil perilaku mahasiswa dalam pemakaian barang yang menyebabkan limbah (consumenarism)

\begin{tabular}{clcc}
\hline No. & \multicolumn{1}{c}{ Perilaku } & Rata-rata & Kategori \\
\hline 1 & Penggunaan kantong plastik saat berbelanja & 3 & cukup \\
2 & Pemanfaatan kembali kertas yang telah digunakan & 4 & tinggi \\
3 & $\begin{array}{l}\text { Mengurangi makanan dan minuman dalam kemasan sekali } \\
\text { pakai }\end{array}$ & 4 & tinggi \\
4 & Penggunaan tisu dalam kehidupan sehari-hari & 4 & tinggi \\
5 & Membakar sampah untuk mengurangi timbunan sampah & 4 & tinggi \\
\hline
\end{tabular}

Sumber: Data primer diolah, 2018

\section{Perilaku Konsumsi yang Ramah Lingkungan (Waste Avidance)}

Salah satu perilaku yang menunjukkan indikator perilaku ramah lingkungan adalah penggunaan bahan baku makanan yang ramah lingkungan. Upaya menciptakan kualitas lingkungan yang sehat dapat dikendalikan oleh masyarakat sebagai konsumen dengan melakukan perubahan memilih dan mengkonsumsi barang tertentu yang ramah terhadap lingkungan. Konsumen yang memiliki kesadaran lingkungan akan memilih produkproduk yang ramah lingkungan meskipun harganya relatif mahal (Laroche et al., 2001; Maguire et al., 2004). Junaedi (2005) menyatakan perbaikan mutu kehidupan dan gaya hidup sehat telah mendorong masyarakat di berbagai negara dan mendorong gerakan gaya hidup sehat dengan tema global kembali ke alam atau back to nature.

Hasil penelitian menunjukkan bahwa gaya hidup mahasiswa pendidikan akuntansi UNNES masih jauh dari gaya hidup back to nature. Kesadaran mahasiswa untuk mengkonsumsi bahan-bahan makanan yang ramah lingkungan masih cukup. Hal ini dimungkinkan karena mahasiswa tidak memiliki daya beli yang tinggi untuk mampu membeli bahan makanan organik yang harganya relatif lebih mahal dari bahan makanan biasa. Hal ini seperti yang dinyatakan oleh Schiffman et al. (2007) bahwa perilaku konsumen mengacu pada bagaimana individu membuat keputusan untuk menggunakan sumber daya (waktu, uang, dan usaha) yang tersedia untuk menggunakan barang konsumsi. Selain rendahnya kemampuan untuk membeli bahan makanan alami, mahasiswa memiliki kecenderungan untuk mengkonsumsi makanan dari hasil peternakan seperti telur dan daging ayam. Dengan alasan perbaikan gizi, mahasiswa hampir setiap hari mengkonsumsi telur dan daging ayam. Di sisi lain, mahasiswa sudah ketergantungan untuk menggunakan bahan kimia sebagai pengusir nyamuk di kos. Selain itu mahasiswa memiliki kebiasaan untuk tidak menghemat air, khususnya pada saat pencucian peralatan yang digunakan sehari-hari. 
Tabel 6 Hasil perilaku mahasiswa dalam perilaku konsumsi yang ramah lingkungan (waste avidance)

\begin{tabular}{clcc}
\hline No. & \multicolumn{1}{c}{ Perilaku } & Rata-rata & Kategori \\
\hline 1 & Konsumsi produk makanan organik & 3 & cukup \\
2 & $\begin{array}{l}\text { Penggunaan insektisida kimia untuk membunuh serangga } \\
\text { cukup }\end{array}$ & 3 & cukup \\
& $\begin{array}{l}\text { Pengurangan gas metana, dengan mengurangi konsumsi } \\
\text { makanan hasil peternakan }\end{array}$ & 3 & tinggi \\
4 & $\begin{array}{l}\text { Menghindari pemakaian barang yang tidak ramah } \\
\text { lingkungan }\end{array}$ & 4 & rendah \\
& $\begin{array}{l}\text { Mencuci peralatan tidak dengan menggunakan air } \\
\text { mengalir }\end{array}$ & 2 & \\
\hline
\end{tabular}

Sumber: Data primer diolah, 2018

\section{Perilaku Memperhatikan Barang-Barang yang Dapat Didaur Ulang (Recycling)}

Marliani (2014) menyatakan bahwa dari sekian limbah rumah tangga ada yang sangat berbahaya bagi kesehatan manusia yaitu sampah anorganik yang keberadaannya kadang dianggap kecil. Sampah anorganik adalah sampah yang dihasilkan dari bahan-bahan non-hayati baik berupa produk sintetik maupun hasil proses teknologi, contohnya botol plastik, tas plastik, kaleng. Sebagai wujud sebagai kampus konservasi, UNNES telah mengeluarkan Peraturan Rektor UNNES Nomor 27 tahun 2012 tentang Tata Kelola Kampus Berbasis Konservasi. dalam pasal 6 disebutkan bahwa warga UNNES termasuk mahasiswa berkewajiban melaksanakan prinsip pengelolaan limbah sesuai prinsip konservasi. Melalui mata kuliah PLH, mahasiswa sudah diajarkan bagaimana mengelola sampah anorganik. Berdasarkan hasil penelitian menunjukkan bahwa mahasiswa pendidikan akuntansi masih memiliki kemampuan untuk pengolahan sampah anorganik dalam kategori cukup. Adanya pusat konservasi, aturan yang dibuat, rumah kompos, mata kuliah PLH, belum cukup mampu untuk membuat mahasiswa memiliki kebiasaan untuk mengolah bahan baku sampah organik menjadi suatu produk yang dapat bermanfaat.

Kebiasaan mahasiswa dalam pengelolaan sampah hanya masih terbatas pada pemisahan sampah organik dan anorganik. Kebiasaan mahasiswa dalam pengelolaan sampah hanya sebatas pemanfaatan paling sederhana yaitu menggunakan kantong plastik sebagai tempat penampungan sampah. Mulasari (2012) menyatakan bahwa stigma masyarakat terkait sampah adalah semua sampah itu menjijikkan, kotor, dan lain-lain sehingga harus dibakar atau dibuang sebagaimana mestinya. Membangun kesadaran masyarakat tidak semudah membalikkan telapak tangan, diperlukan waktu yang cukup lama untuk membangun kesadaran pengelolaan sampah (Rizal, 2011). Diperlukan keterlibatan aktif mahasiswa dalam kegiatan-kegiatan pengelolaan sampah yang dilakukan oleh pihak kampus, misalkan melibatkan mahasiswa dalam kegiatan pengabdian masyarakat dosen, melakukan gerakan pengelolaan sampah anorganik secara massal oleh mahasiswa menggantikan kegiatan rutin yang berupa penanaman pohon.

Tabel 7 Hasil perilaku mahasiswa dalam daur ulang limbah (recycling)

\begin{tabular}{|c|c|c|c|}
\hline No. & Perilaku & Rata-rata & Kategori \\
\hline 1 & Melakukan daur ulang kertas bekas & 3 & cukup \\
\hline 2 & Pemanfaatan sampah botol plastik untuk didaur ulang & 3 & cukup \\
\hline 3 & Pengolahan sampah organik menjadi kompos & 3 & cukup \\
\hline 4 & $\begin{array}{l}\text { Pemisahan sampah menjadi sampah organik dan } \\
\text { anorganik }\end{array}$ & 4 & tinggi \\
\hline 5 & Pemanfaatan kantong plastik sebagai tempat sampah & 4 & tinggi \\
\hline
\end{tabular}

Sumber: Data primer diolah, 2018 


\section{Perilaku Sosial yang Menggambarkan Kepedulian Terhadap Lingkungan (Vilarious, Social Behaviors Toward Conservation)}

Indikator yang menunjukkan perilaku ramah terhadap lingkungan adalah perilaku sosial yang berupa kepedulian terhadap lingkungan. Bagaimana masyarakat mau berkorban secara sosial demi kelestarian lingkungan, misalnya terlibat dalam organisasi lingkungan, bersedia mengorbankan sebagian dana untuk kegiatan lingkungan, bahkan secara aktif melalui media sosial untuk mengikuti isu lingkungan terkini dan menghimbau masyarakat lain untuk peduli terhadap lingkungan. UNNES sebagai kampus konservasi, memberikan ruang kepada mahasiswa untuk menjadi kader konservasi yang bertugas untuk membantu UNNES menjadi kampus konservasi dan bereputasi internasional. Dengan menjadi kader konservasi mahasiswa akan diajarkan berbagai kegiatan yang berhubungan dengan lingkungan, dan memiliki komunitas baru dalam lingkungan.

Berdasarkan hasil penelitian menunjukkan bahwa tingkat ketertarikan mahasiswa untuk tergabung dalam organisasi lingkungan, mengikuti isu-isu lingkungan, dan kepedulian untuk membersihkan lingkungan setelah berkegiatan dalam kategori cukup. Mahasiswa belum merasakan manfaat yang dapat diterima dengan mengikuti organisasi lingkungan sehingga masih enggan untuk menjadi anggota organisasi, khusunya kader konservasi di UNNES. Melalui UPT Konservasi, UNNES mewajibkan mahasiswa untuk menanam pohon minimal lima pohon selama kuliah di UNNES. Sehingga secara finansial mahasiswa sudah terdorong untuk mengorbankan sebagian dananya untuk membeli pohon yang akan ditanam di sekitar kampus, maupun saat pengabdian kepada masyarakat dalam bentuk Kuliah Kerja Nyata (KKN). Meskipun pengorbanan ini masih bersifat paksaan, namun demikian kebijakan yang dilakukan UNNES ingin menumbuhkan semangat peduli lingkungan kepada mahasiswa.

Tabel 8 Perilaku sosial mahasiswa yang menggambarkan kepedulian terhadap lingkungan (vilarious, social behaviors toward conservation)

\begin{tabular}{|c|c|c|c|}
\hline No. & Perilaku & Rata-rata & Kategori \\
\hline 1 & $\begin{array}{l}\text { Membersihkan kembali tempat piknik setelah selesai } \\
\text { berlibur }\end{array}$ & 3 & cukup \\
\hline 2 & Gemar membaca dan mengikuti isu-isu terkait lingkungan & 3 & cukup \\
\hline 3 & Keterlibatan dalam organisasi lingkungan & 3 & cukup \\
\hline 4 & Berkontribusi secara finansial untuk organisasi lingkungan & 4 & tinggi \\
\hline 5 & $\begin{array}{l}\text { Memanfaatkan sosial media, membuat tulisan berupa } \\
\text { himbauan agar orang lain peduli terhadap lingkungan }\end{array}$ & 4 & tinggi \\
\hline
\end{tabular}

Sumber: Data primer diolah, 2018

Mahasiswa sebagai generasi milenial tidak pernah lepas dari media sosial. Berbagai isu, topik, akan diminati mahasiswa, termasuk permasalahan lingkungan. Berdasarkan hasil penelitian, menunjukkan bahwa mahasiswa memiliki minat yang tinggi untuk menghimbau masyarakat untuk terus melestarikan alam. Meskipun secara umum perilaku mahasiswa pendidikan akuntansi UNNES dalam kategori cukup untuk perilaku sosial, namun pihak kampus tidak menutup mata untuk selalu memberikan ruang dan media bagi mahasiswa untuk mengembangkan perilaku kepedulian terhadap lingkungan. Hawkins and Mothersbaugh (2010) menyatakan untuk mampu merubah perilaku sesorang, pertama-tama harus mengubah pikiran positif orang tersebut terhadap lingkungan sehingga orang tersebut dapat berperilaku dengan tepat. Perubahan perilaku bukanlah sesuatu yang langsung, melainkan hasil dari proses pembangunan. 


\section{KESIMPULAN}

Berdasarkan hasil penelitian diketahui bahwa dalam enam kategori pengukuran perilaku ramah lingkungan mahasiswa pendidikan akuntansi, terdapat tiga indikator dalam kategori tinggi dan tiga indikator dalam kategori cukup. Berbagai upaya telah dilakukan oleh pihak UNNES untuk merealisasikan tujuan universitas menjadi universitas konservasi. Sebagai langkah kongkritnya yaitu dengan mendirikan pusat konservasi yang lengkap dengan segala aturan dan sarana prasarana yang ada. Dan dengan menginternalisasikan karakteristik konservasi kepada mahasiswa melalui penambahan mata kuliah Pendidikan Lingkungan Hidup (PLH) ke dalam kurikulum seluruh program studi di UNNES. Kepedulian mahasiswa untuk menggunakan energi ramah lingkungan, penggunaan transportasi yang ramah lingkungan, pemakaian bahan yang ramah lingkungan merupakan perilaku yang dapat dibanggakan. Kebijakan untuk menggunakan sepeda di dalam kampus, kegiatan penghijauan kampus dan lingkungan sekitar mampu membuat mahasiswa untuk memiliki perasaan tanggung jawab kepada lingkungan.

Saran yang dapat diberikan atas hasil penelitian ini adalah meningkatkan kesadaran mahasiswa untuk lebih kreatif terutama dalam pengelolaan sampah anorganik. Mahasiswa perlu lebih dilibatkan dalam kegiatankegiatan pengabdian kepada masyarakat yang dilakukan oleh dosen, maupun dapat melalui praktik kewirausahaan calon industri kreatif pada saat mahasiswa menempuh mata kuliah kewirausahaan yang selama ini mata kuliah ini identik dengan praktik perdagangan makanan. Selain itu, pihak universitas untuk lebih meningkatkan sosialisasi kepada mahasiswa melalui UPT Konservasi akan adanya kader konservasi, dan kader konservasi yang sudah terbentuk untuk dapat mengimplementasikan kinerja nyata kebermanfaatan mahasiswa terhadap lingkungan. Diharapkan dapat meningkatkan kerja sama dengan lembaga pemerintah terkait lingkungan, sehingga mahasiswa akan lebih tertarik untuk mengikuti organisasi-organisasi lingkungan baik yang didirikan oleh UNNES maupun organisasi eksternal yang ada di Kota Semarang.

\section{DAFTAR PUSTAKA}

Arif A, Permanasari I, Badil R. 2009. Hidup Hirau Hijau: Langkah Menuju Hidup Ramah Lingkungan. Jakarta (ID): KPG (Kepustakaan Populer Gramedia).

Bechtel RB, Churchman A. 2002. Environmental Psychology. New York (US): Wiley \& Sons, Inc.

Corral-Verdugo V, Frías-Armenta M. 2006. Personal normative beliefs, antisocial behavior, and residential water conservation. Environment and Behavior. 38(3): 406-421. doi: 10.1177/0013916505282272.

Eilam E, Trop T. 2012. Environmental attitudes and environmental behavior-which is the horse and which is the cart?. Sustainability. 4(9): 2210-2246.

Fu L, Zhang Y, Xiong X, Bai Y. 2018. Pro-environmental awareness and behaviors on campus: evidence from Tianjin, China. Eurasia Journal of Mathematics, Science and Technology Education. 14(1): 427-445. doi: 10.12973/ejmste/77953.

Harland P, Staats H, Wilke HAM. 2007. Situational and personality factors as direct or personal norm mediated predictors of pro-environmental behavior: Questions derived from norm-activation theory. Basic and Aplied Social Psychology. 29(4): 323-334.

Hawkins DI, Mothersbaugh DL. 2010. Consumer Behavior: Building Marketing Strategy. Boston (US): McGraw-Hill Irwin.

Hidup SDSL. 2009. Indikator Perilaku Peduli Lingkungan Hidup (Hasil Survei Perilaku Peduli Lingkungan Hidup di 33 Ibu Kota Provinsi). Jakarta (ID): Badan Pusat Statistik.

Ikhsandri. 2014. Kajian infrastruktur pengolahan sampah di kawasan berkembang Jakabaring Kelurahan 15 Ulu Kota Palembang. Jurnal Teknik Sipil dan Lingkungan. 2(1): 130-145.

Junaedi MFS. 2005. Pengaruh kesadaran lingkungan pada niat beli produk hijau: Studi perilaku konsumen berwawasan lingkungan. BENEFIT. 9(2): 189-201. 
Jurdi-Hage R, Hage HS, Chow HPH. 2019. Cognitive and behavioural environmental concern among university students in a Canadian city: Implications for institutional interventions. Australian Journal of Environmental Education. 35(1): 28-61. doi: 10.1017/aee.2018.48.

Kaiser FG, Wolfing S, Fuhrer U. 1999. Ennvironmental attitude and ecological behaviour. Journal of Environmental Psychology. (19): 1-19.

Kollmus A, Agyeman J. 2002. Mind the gap: Why do people act environmentally and what are the barriers to pro-environmental behavior?. Environmental Education Research. 8(3): 239-260.

Laroche M, Bergeron J, Barbaro-Forleo G. 2001. Targeting consumers who are willing to pay more for environmentally friendly products. Journal of Consumer Marketing. 18(6): 503-520. doi: doi:10.1108/EUM0000000006155.

Lin E, Shi Q. 2014. Exploring individual and school-related factors and environmental literacy: Comparing U.S. and Canada using PISA 2006. Int $J$ of Sci and Math Educ. 12: 73-97. doi: https://doi.org/10.1007/s10763-012-9396-2.

Lukman R, Lozano R, Vamberger T, Krajnc M. 2013. Addressing the attitudinal gap towards improving the environment: A case study from a primary school in Slovenia. Journal of Cleaner Production. 48: 93100. doi: https://doi.org/10.1016/j.jclepro.2011.08.005.

Rodríguez-Barreiro LM, Fernández-Manzanal R, Serra LM, Carrasquer J, Murillo MB, Morales MJ, Calvo JM, Valle J. 2013. Approach to a causal model between attitudes and environmental behaviour. A graduate case study. Journal of Cleaner Production. 48: 116-125.

Maguire KB, Owens N, Simon NB. 2004. The price premium for organic babyfood: A hedonic analysis. Journal of Agricultural and Resource Economics. 29(1): 132-149.

Marliani N. 2014. Pemanfaatan limbah rumah tangga (sampah anorganik) sebagai bentuk implementasi dari pendidikan lingkungan hidup. Jurnal Formatif. 4(2): 124-132.

Mcfarlane BL, Boxall P. 2003. The role of social psychological and social structural variables in environmental activism. Journal of Environmental Psychology. 23(1): 79-87. doi: 10.1016/S0272-4944(02)00080-4.

Meyer A. 2016. Heterogeneity in the preferences and pro-environmental behavior of college students: the effects of years on campus, demographics, and external factors. Journal of Cleaner Production. 112: 3451-3463. doi: https://doi.org/10.1016/j.jclepro.2015.10.133.

Mulasari SA. 2012. Hubungan tingkat pengetahuan dan sikap terhadap perilaku masyarakat dalam mengolah sampah di Dusun Padukuhan Desa Sidokarto Kecamatan Godean Kabupaten Sleman Yogyakarta. Kes Mas. 6(3): 204-211. doi: http://dx.doi.org/10.12928/kesmas.v6i3.1055.

Nordlund AM, Garvill J. 2003. Effects of values, problem awareness, and personal norm on willingness to reduce personal car use. Journal of Environmental Psychology. 23(4): 339-347. doi: 10.1016/s02724944(03)00037-9.

Ritter AM, Borchardt M, Vaccaro GLR, Pereira GM, Almeida F. 2015. Motivations for promoting the consumption of green products in an emerging country: Exploring attitudes of Brazilian consumers. Journal of Cleaner Production. 106: 507-520. doi: https://doi.org/10.1016/j.jclepro.2014.11.066.

Rizal M. 2011. Analisis pengelolaan persampahan perkotaan (Sudi kasus pada Kelurahan Boya Kecamatan Banawa Kabupaten Donggala). Jurnal SMARTek. 9(2): 155-172.

Schiffman L, Bednall D, O`Cass A, Paladino A, Kanuk L. 2007. Consumer Behaviour. Australia (AU): Pearson Education Australia.

Schultz PW, Gouveia VV, Cameron LD, Tankha G, Schmuck P, Franěk M. 2005. Values and their relationship to environmental concern and conservation behavior. Journal of Cross-Cultural Psychology. 36(4): 457475. doi: $10.1177 / 0022022105275962$.

Schwartz SH. 2012. An overview of the schwartz theory of basic values. Online Readings in Psychology and Culture. 2(1). doi: 10.9707/2307-0919.1116.

Steg L, Vlek C. 2009. Encouraging pro-environmental behavior: An integrative review and research agenda. Journal of Environmental Psychology. 20(3): 309-317. doi: 10.1016/j.jenvp.2008.10.004. 
Tompodung TCG, Rushayati SB, Aidi MN. 2018. Efektivitas program adiwiyata terhadap perilaku ramah lingkungan warga sekolah di Kota Depok. Jurnal Pengelolaan Sumber Daya Alam. 8(2):170-177. doi: 10.29244/jps1.8.2.170-177.

Vicente-Molina MA, Fernández-Sáinz A, Izagirre-Olaizola J. 2013. Environmental knowledge and other variables affecting pro-environmental behaviour: Comparison of university students from emerging and advanced countries. Journal of Cleaner Production. 61: 130-138. doi: 10.1016/j.jclepro.2013.05.015.

Zsóka Á, Szerényi ZM, Széchy A, Kocsis T. 2013. Greening due to environmental education? Environmental knowledge, attitudes, consumer behavior and everyday pro-environmental activities of Hungarian high school and university students. Journal of Cleaner Production. 48: 126-138. doi: 10.1016/j.jclepro.2012.11.030. 